\title{
Effects of Soil Conservation Practices on Sediment Yield from Forest Road Ditches in Northern Iran
}

\author{
Rasoul Khandouzi, Aidin Parsakhoo, Vahedberdi Sheikh, \\ Aliakbar Mohamadali Pourmalekshah
}

\begin{abstract}
The fine-textured soil in forest road ditches is very susceptible to water erosion especially in rainy seasons in Hyrcanian forest. This study examined the yield of ditch segment-scale sediment after releasing two flow rates of $5 \mathrm{ls}^{-1}$ and $10 \mathrm{l} \mathrm{s}^{-1}$ in segments treated by riprap (RR), grass cover by Festuca arundinacea L. (GC), compacted cotton geotextile (CG) and wooden wattle by local slash (WW). Sediment sampling from the runoff was carried out at the end of each segment every minute. Runoff flow velocity in different treatments was measured using an electromagnetic flow meter. Sediment concentration and runoff velocity in treatments of $R R, G C, C G, W W$ was significantly lower than that of the control plot (Ctl). Increasing flow rate from $5 \mathrm{ls}^{-1}$ to $10 \mathrm{ls}^{-1}$ caused no significant change in sediment concentration (except for $C t l$ and $R R$ ) and runoff velocity (except for $C t l$ and $C G$ ), which means that some water might have penetrated into treated soil by RR, GC and WW and this is not acceptable in forest road maintenance practices. Sediment yield from $R R\left(0.36 \mathrm{gl}^{-1}\right)$ and $C t l\left(0.50 \mathrm{gl}^{-1}\right)$ under the flow rate of $10 \mathrm{l} \mathrm{s}^{-1}$ was significantly higher than that of $5 \mathrm{ls}^{-1}$ with values of $0.21 \mathrm{gl}^{-1}$ and $0.38 \mathrm{gl}^{-1}$, respectively. Minimum amount of sediment concentration was observed for CG $\left(0.20 \mathrm{gl}^{-1}\right)$ with compacted ditch bed. Moreover, runoff velocity in CG and $C t l$ under the flow rate of $10 \mathrm{l} \mathrm{s}^{-1}$ was significantly higher than that of $5 \mathrm{ls}^{-1}$. For a forest road with dimension $30 \times 50 \mathrm{~cm}$, slope of $5 \%$, and clay soil with porosity of $57 \%$, treatments of compacted CG can be used in ditch with low flow rates $\left(5 l \mathrm{~s}^{-1}\right)$ and high flow rate $\left(10 l \mathrm{~s}^{-1}\right)$ because of their high efficiency in reducing sediment yield.
\end{abstract}

Keywords: conservation treatments, cotton geotextile, flow simulation, sediment concentration, water erosion

\section{Introduction}

Forest roads provide easy and quick access to forest regions in order to harvest wood and non-wood products, provide forest protection, recreation, forestry and education (Demir and Hasdemir 2005, Galia et al. 2017). On the one hand, due to the high cost of construction and maintenance, these roads are considered as one of the most important investments in forest management and at the same time they are viewed as the largest human intervention in the wild and dynamic forest ecosystems (Foltz et al. 2009, Stenberg et al. 2015). By causing natural deformation of the slope, cutting down the surface and subsurface flow, reducing the vegetation cover, and finally, increasing soil compaction, especially on the road surface, forest roads lead to the increase in the velocity of runoff, cause exacerbation in erosion and sediment production in the adjacent ditch (Tague and Band 2001, Forsyth et al. 2006, Efta and Chung 2014, Lang 2016, Streeter et al. 2019). The rate of ditch sediment is influenced by factors such as soil type (Daly et al. 2017), velocity and shear stress of runoff (Falbo et al. 2013, Haahti et al. 2014), geometric shape of ditch (Kumwimba et al. 2016), slope gradient (Broda et al. 2016, Matthew et al. 2019). Materials detached from the ditch contain nutrients (macro and microelements), solids and organics, which are suspended as 
sediment load (Vymazal and Březinová 2018, Schilling et al. 2018).

The temporary and/or permanent stabilization of ditch using environmentally friendly techniques and/ or mechanical operations can be regarded as a useful measure in the reduction of sediment yield from roads to canals and rivers (Jia et al. 2019). In temporary stabilization techniques through the deployment of vegetation cover, geotextile installation, etc., straw and wood mulch can be found that is usually deteriorated after several years (Appelboom et al. 2002). In permanent stabilization techniques, ditch stabilization is performed by deployment of hard covers such as concrete and riprap and flexible covers such as seasonal grasslands (Cerdá 2001, Flora and Kröger 2014, Dollinger et al. 2017). Broda et al. (2016) used woolen, woolencotton and recycled fiber geotextile for the stabilization of forest road ditches with thicknesses of 5.8, 3 and $3 \mathrm{~mm}$, and masses of 406, 512 and $265 \mathrm{~g} \mathrm{~m}^{-2}$, respectively. The results showed that water absorption capacity of woolen geotextile was higher than that of woolen-cotton and recycled fibers. Javadi et al. (2005) investigated the effect of using riprap on sediment concentration under rainfall simulation experiments in soil erosion laboratory of Forest and Rangeland Research Institute. The results showed that, by increasing the percentage of riprap, sediment yield reduced significantly compared to the bare soil as control. Afzalimehr and Dey (2009) reported that two factors of using riprap and vegetation cover led to the reduction of runoff velocity and, as a result, the erosive power reduced. Wang et al. (2012) covered $40 \%$ of ditch bed by riprap, then they evaluated the effect of this treatment on the characteristics including runoff velocity, infiltration rate and sediment yield under three simulated rainfall intensities $\left(57,91\right.$, and $122 \mathrm{~mm} \mathrm{~h}^{-1}$ ) and they compared the results with those obtained from the control (bare soil). The results showed that runoff velocity, sediment concentration and soil erosion rate were significantly reduced when using riprap treatment. Soil erosion rate was less than $12 \mathrm{~g} \mathrm{~m}^{-2} \mathrm{~min}^{-1}$ for riprap treatment at $122 \mathrm{~mm} \mathrm{~h}^{-1}$ of rainfall intensity, whereas for control with rainfall intensity of $57 \mathrm{~mm} \mathrm{~h}^{-1}$ was estimated to be more than $15 \mathrm{~g} \mathrm{~m}^{-2} \mathrm{~min}^{-1}$.

Different methods have been used to estimate the sediment concentration of forest road ditches, including the use of sediment fence and ditch sampling under natural and simulated runoff using motor pump (Nearing et al. 1991, Robichaud and Brown 2002, Hamed et al. 2002). Considering the cost of measuring sediment yield under natural rainfall conditions and since it is not possible to control the performance of operation under natural rainfall in terms of time, the use of a runoff simulator pump is a suitable method estimate the sediment concentration of forest road ditches (Boulange et al. 2019). Since 1965, several experiments have been performed to study the effect of runoff on soil erosion (Sheridan et al. 2008). Lyle and Smerdon (1965) found a significant relationship between sediment yield and shear stress of runoff in a steady slope. Other experiments were performed by creating simulated runoff using a water pump on different slopes to evaluate the relationship between sediment yield rate and variables such as slope gradient, shear stress and flow velocity. Logarithmic relationship was found between sediment yield and the studied variables. Cao et al. (2009) conducted a study at Chinaś Research Center of Soil and Water Conservation, and they studied the sediment yield of earthy roads influenced by runoff. Runoff simulation experiments were performed on the road surface using a pump with a discharge capacity of 1 to $51 \mathrm{~s}^{-1}$. The results showed that sediment yield of the roads was significantly influenced by factors such as flow depth and road slope and other hydraulic variables such as shear stress and flow power. The ditch is designed to drain runoff from the road surface and prevent the flow from reaching to the pavement surface, thereby protecting the road structure and ensuring the safety of the drivers and pedestrians (Luce and Black 1999, Lin et al. 2011). A good water management plan regarding the ditch includes conservation by the use of natural products, which can be cost effective and useful. Therefore, the use of environmentally friendly techniques is essential for protecting the ditch.

\subsection{Research Objectives}

The main objective is to design and implement soil erosion control treatments in forest road ditches to measure and record sediment yield and identify best conservation practices.

Another objective is to produce two flow intensity in the ditch to investigate changes in the sediment concentration in different conservation treatments.

\section{Material and Methods}

\subsection{Description of Study Area}

District 1 in Shast Kalateh forests with an area of 1713 hectares is located in Golestan province, northern Iran ( $36^{\circ} 43^{\prime} 27^{\prime \prime}$ to $36^{\circ} 48^{\prime} 6^{\prime \prime} \mathrm{N}$ and $54^{\circ} 21^{\prime} 26^{\prime \prime}$ to $\left.54^{\circ} 24^{\prime} 57^{\prime \prime} \mathrm{E}\right)$. The bedrock of this forest is lime and sand stone with altitude ranging from 100 to $1000 \mathrm{~m}$ above sea level. This is a mixed broadleaf deciduous forest, established on brown forest soil with mostly clay-loam-silty texture 

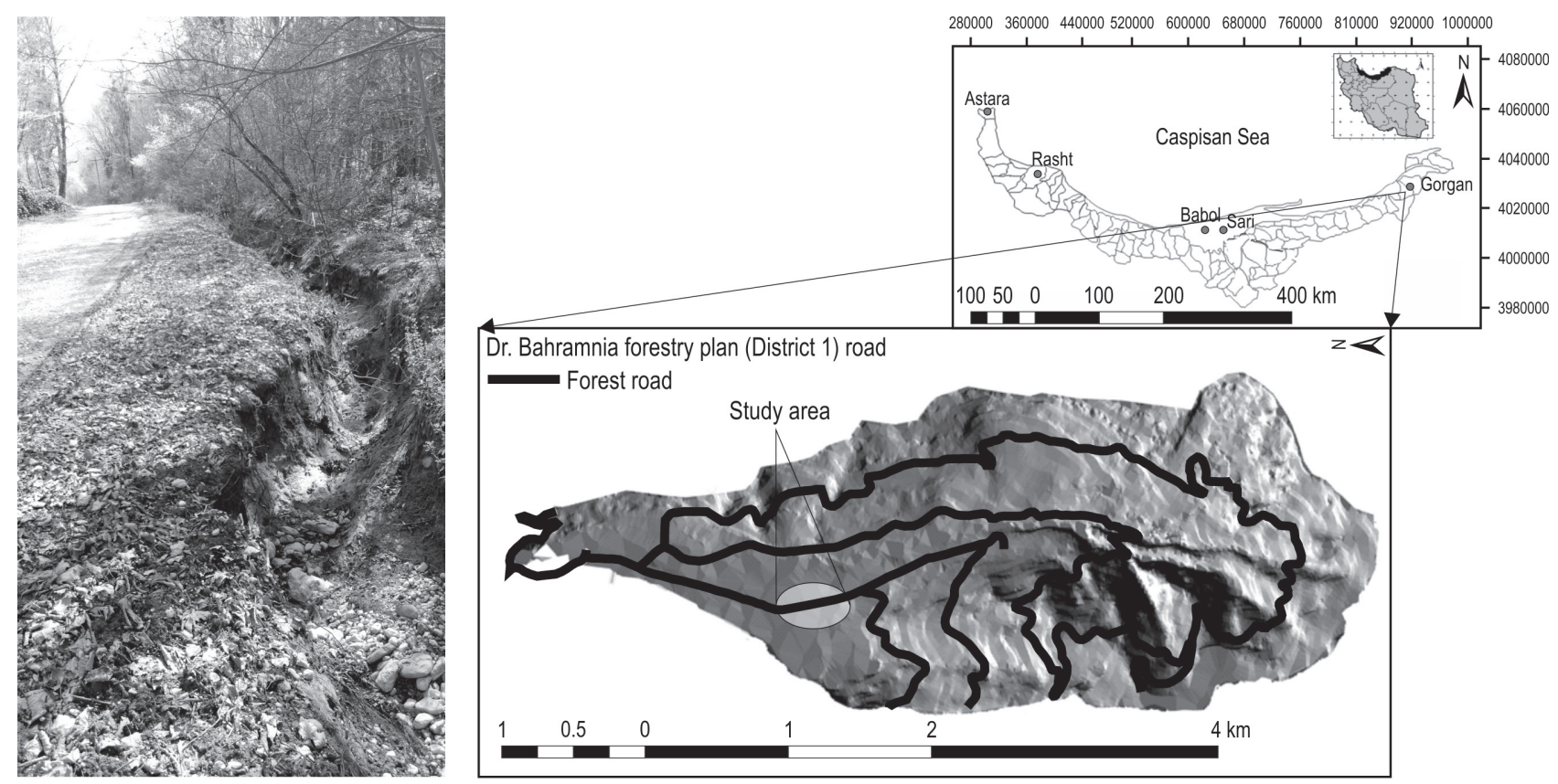

Fig. 1 Study area

and natural worn stones. The mean forest stock growth in the study area was $247 \mathrm{~m}^{3} \mathrm{ha}^{-1}$. The climate of the region is Mediterranean warm and moist with mean annual precipitation of $686 \mathrm{~mm}$. The minimum mean monthly rainfall is in August $(31 \mathrm{~mm}$ ) and the maximum in March $(79 \mathrm{~mm}$ ). In Shast Kalateh forests, $30.3 \mathrm{~km}$ of forest roads were constructed in 1989. The width and general slope of roads were 5.5 meter and $5 \%$, respectively. Road template was crown and the mean distance of culverts was $500 \mathrm{~m}$. The ditches of these roads are very susceptible to erosion, and in rainy seasons gully erosion occurrs (Fig. 1). The curve of the particle size distribution and soil texture for each treated ditch in the study area are shown in Fig. 2.

\subsection{Treatment Establishments}

The case study is based on five ditch segments, each with a length of $10 \mathrm{~m}$, which are located in Shast Kalateh forest road network. A 2-meter buffer zone was considered between segments to exit runoff flow, collect sediment data and prevent the influence of one treatment to another (Lang 2016). The mean longitudinal slope gradient of segments was $5 \%$. In the present study, except for shear stress and velocity of runoff, other factors are constant for all treatments. The ditches of road sections were treated by conservation practices. Ditch bed was compacted before the implementation of some treatments (CG, RR and GC) to prevent water penetration into road subbase. The soil particle size distribution of ditch bed was deter- mined using dry sieving method. The saturated moisture content was measured using corrected soil porosity method (Williams et al. 1992). The treatments included the use of riprap (RR), grass cover by Festuca arundinacea L. (GC), cotton geotextile (CG), wooden wattle by local slash (WW) and control (Ctl)

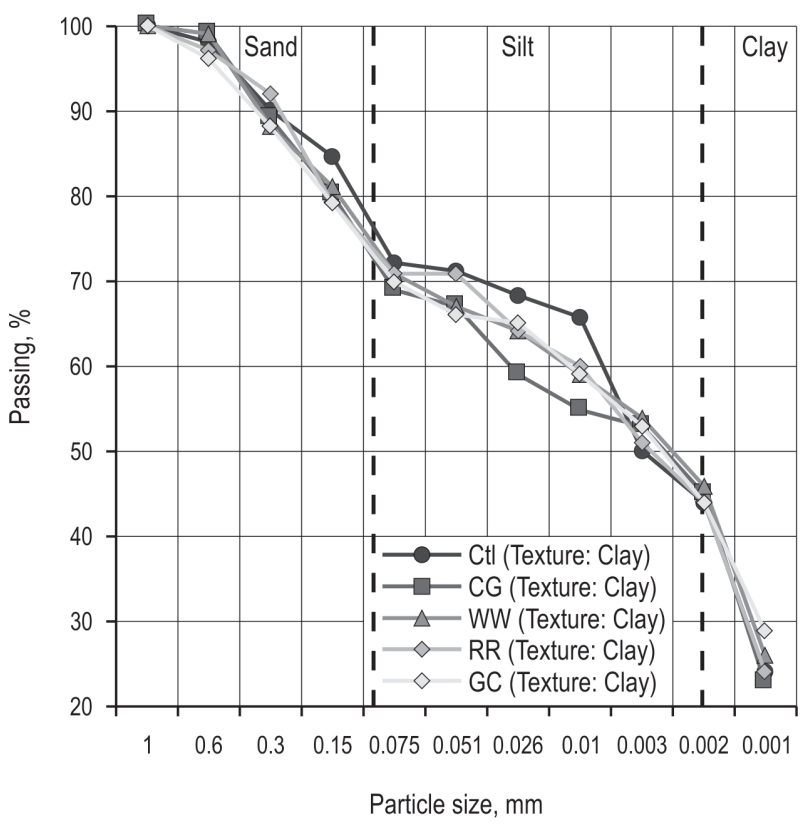

Fig. 2 Soil grain curve and classification for each treatment based on USDA soil taxonomy 

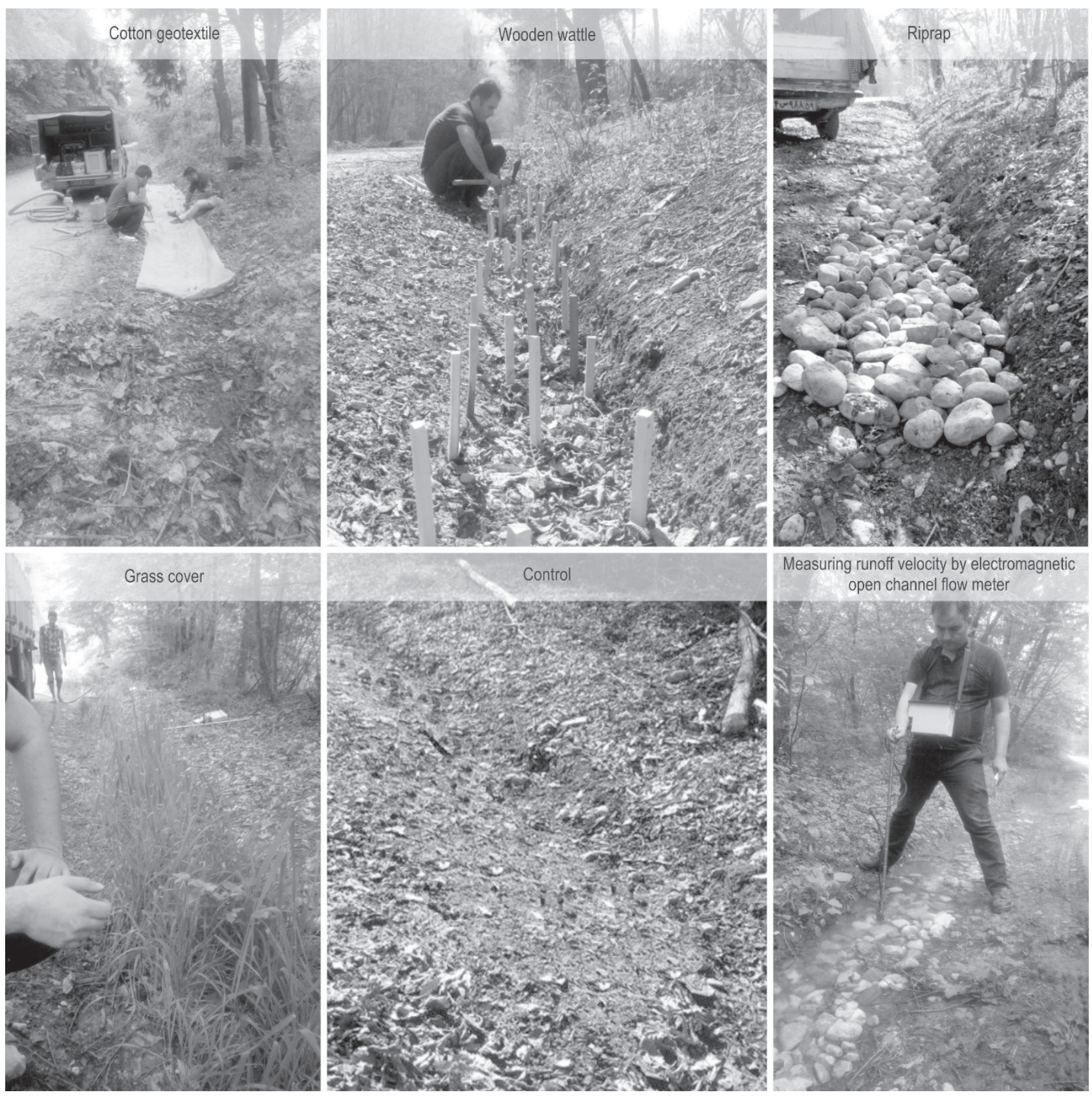

Measuring runoff velocity by electromagnetic open channel flow meter

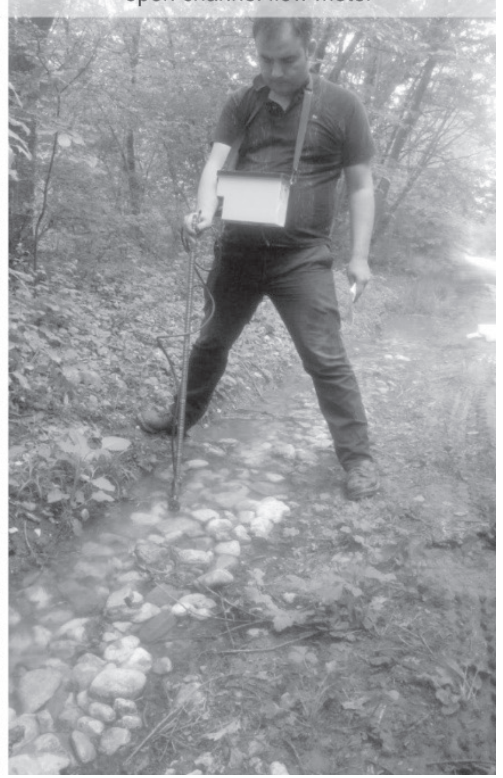

Fig. 3 Conservation treatments of ditch

(Fig. 3). Local stream materials were used with an average volume of $220 \mathrm{~cm}^{-3}$ (Fragment volumes were calculated using Archimedes' principle) and mass value of $600 \mathrm{~g}$ (Fragment masses were calculated using digital balance) for each fragment in order to perform the riprap establishment (Wang et al. 2012). Cotton geotextile with a thickness of two mm and mass per square meter of $220 \mathrm{~g}$ was installed on ditch bed by wooden nails (Lotfalian et al. 2019). Local slash, with average diameter of $3 \mathrm{~cm}$ and length of $50 \mathrm{~cm}$, was scraped and then used for wooden wattle construction on the ditch. Grass cover was established using Festuca arundinacea L. on the ditch with seed density of $70 \mathrm{~g} \mathrm{~m}^{-2}$ (Shixiong Cao et al. 2006). A bare soil with a length of 10 meter was selected as the control treatment for the ditch.

\subsection{Runoff Simulation and Data Collection}

Flow simulation was done for ten minutes at two flow rates of 5 and $101 \mathrm{~s}^{-1}$ using a tank with the capacity 


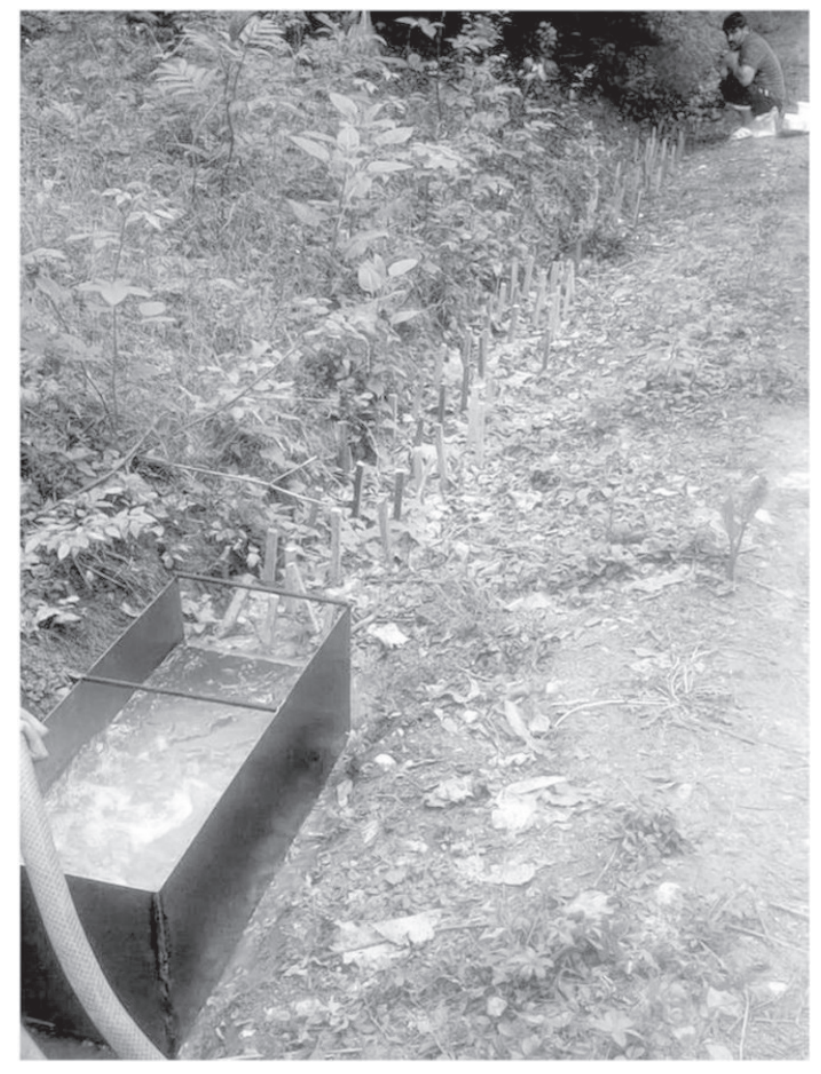

Fig. 4 Runoff simulation and sediment sampling at the end of each road section

of 6000 liters equipped with a motor-pump (Nearing et al. 1991, Cao et al. 2009). In order to decrease the initial flow intensity and simulate the local natural flow, a steel tube similar to the dimensions of the ditch, with a length of one meter, was provided (Fig. 4). Sediment sampling from the runoff was carried out at the end of each section every minute. Samples were transported to the laboratory and their sediment was calculated in $\mathrm{gl}^{-1}$. The pure water was separated from deposited sediment. The sediment was air-dried for a week at the temperature of $30^{\circ} \mathrm{C}$. Besides, it was ovendried at $105^{\circ} \mathrm{C}$ for at least 24 hours and then weighted using a digital balance (Coker et al. 1993). Eq. 1 was used to calculate sediment concentration (Burroughs et al. 1991):

$$
S C=S Y / R V
$$

Where:

SC sediment concentration, $\mathrm{g}^{-1}$

$S Y$ sediment mass (g) and $R V$ is the runoff volume, 1 .

Runoff flow velocity in different treatments was measured with three replications using an electromagnetic flow meter (Fig. 4).

\subsection{Statistical Analysis}

Factorial design was used to analyze quantitative factors of sediment concentration and runoff velocity. Conservation treatments and flow rate had 5 and 2 levels, respectively. Totally, 100 samples were collected for sediment analysis and 60 samples for runoff velocity. Data were statistically analyzed using GLM procedure in SAS program. LSD test was used to compare means among treatments and diagram designed by Excel software.

\section{Results and Discussion}

\subsection{Effect of Conservation and Flow Treatments on Sediment Concentration}

Comparison of some soil characteristics including sand, silt, clay and moisture content showed no significant differences among treatments (Table 1). The results of analysis of variance showed that conservation treatments and flow rates had a significant effect on sediment concentration. Soil surface roughness has a significant influence on water erosion, related to runoff velocity and concentration sediments. In this study, the roughness of CG, RR, GC and WW treatments increases surface tortuosity and, therefore, decreases runoff velocity and its ability to detach the soil as compared with Ctl. It was detected that CG performed well under certain circumstances due to the compaction practice prior to implementation of the treatment (Table 2). Indeed, soil cover with CG is more effective than other treatments in reducing runoff velocity, with acceptable range and sediment yield. A superior result of CG was also observed by Lotfalian et al. (2019) in the stabilization of forest road cutslopes. They found that, in this treatment, soil loss was reduced by 12.5 and 6 times compared to the $\mathrm{Ctl}$ plot on the new and old cutslopes, respectively, due to through cover of the surface. Broda et al. (2016) introduced the high absorption capacity and CG as the main contributors to the reduction of sediment concentration, and their results are in agreement with the results of the present study. WW provided numerous obstacles against stress force of runoff and suspended sediment. So wooden obstacles provided the necessary time for water infiltration in soil and deposition of sediment, and consequently the sediment concentration was reduced, but water penetration into the sub base of the forest road is not acceptable in road conservation practices.

The results of the current study are not consistent with the results of the study by Javadi et al. (2005), Wang et al. (2012) and Lang (2016). They implemented five treatments including Ctl (bare soil), GC, GC on 
Table 1 Soil characteristics of ditches containing different conservation treatments

\begin{tabular}{|c|c|c|c|c|c|c|}
\hline \multirow{2}{*}{ Variables } & & \multicolumn{5}{|c|}{ Treatment } \\
\hline & & Control & Cotton geotextile & Wooden wattle & Riprap & Grass cover \\
\hline \multirow{2}{*}{ Sand, \% } & Mean & $28.11^{\mathrm{a}}$ & $31.12^{\mathrm{a}}$ & $29.31^{\mathrm{a}}$ & $29.21^{\mathrm{a}}$ & $30.00^{\mathrm{a}}$ \\
\hline & Standard deviation & 3.32 & 4.12 & 3.13 & 4.21 & 2.12 \\
\hline \multirow{2}{*}{ Silt, \% } & Mean & $28.22^{\mathrm{a}}$ & $24.12^{a}$ & $25.21^{\mathrm{a}}$ & $27.18^{\mathrm{a}}$ & $26.14^{\mathrm{a}}$ \\
\hline & Standard deviation & 3.01 & 4.02 & 4.32 & 5.21 & 3.00 \\
\hline \multirow{2}{*}{ Clay, \% } & Mean & $44.21^{\mathrm{a}}$ & $45.01^{\mathrm{a}}$ & $46.03^{\mathrm{a}}$ & $44.14^{\mathrm{a}}$ & $44.10^{\mathrm{a}}$ \\
\hline & Standard deviation & 5.12 & 4.01 & 5.01 & 6.14 & 6.00 \\
\hline \multirow{2}{*}{ Bulk density, $\mathrm{g} \mathrm{cm}^{-3}$} & Mean & $1.11^{\mathrm{c}}$ & $1.31^{\mathrm{a}}$ & $1.12^{\mathrm{c}}$ & $1.23^{\mathrm{b}}$ & $1.20^{\mathrm{b}}$ \\
\hline & Standard deviation & 0.21 & 0.12 & 0.22 & 0.31 & 0.23 \\
\hline \multirow{2}{*}{ Soil moisture, \% } & Mean & $53.22^{\mathrm{a}}$ & $46.12^{\mathrm{a}}$ & $53.12^{\mathrm{a}}$ & $49.03^{\mathrm{a}}$ & $50.04^{a}$ \\
\hline & Standard deviation & 5.12 & 4.21 & 3.33 & 4.01 & 4.12 \\
\hline
\end{tabular}

Different superscripts in a row show significant difference at probability level of $5 \%$

Table 2 Comparison of different treatments in terms of sediment concentration

\begin{tabular}{|c|c|c|c|c|c|c|c|c|}
\hline \multirow{2}{*}{ Variables } & \multirow{2}{*}{ Flow rates } & & \multicolumn{5}{|c|}{ Treatment } & \multirow[t]{2}{*}{ ANOVA, $p$} \\
\hline & & & Control & Cotton geotextile & Wooden wattle & Riprap & Grass cover & \\
\hline \multirow{4}{*}{$\begin{array}{l}\text { Sediment } \\
\text { concentration, } \mathrm{gl}^{-1}\end{array}$} & \multirow{2}{*}{$5 \mid \mathrm{s}^{-1}$} & Mean & $0.38^{\mathrm{a}}$ & $0.19^{b}$ & $0.25^{b}$ & $0.21^{b}$ & $0.22^{b}$ & \multirow{2}{*}{0.009} \\
\hline & & Standard deviation & 0.04 & 0.01 & 0.02 & 0.01 & 0.01 & \\
\hline & \multirow{2}{*}{$10 \mid \mathrm{s}^{-1}$} & Mean & $0.50^{\mathrm{a}}$ & $0.21^{\mathrm{c}}$ & $0.21^{\mathrm{c}}$ & $0.36^{b}$ & $0.30^{\mathrm{b}}$ & \multirow{2}{*}{0.007} \\
\hline & & Standard deviation & 0.04 & 0.02 & 0.02 & 0.03 & 0.03 & \\
\hline
\end{tabular}

Different superscripts in a row show significant difference at probability level of $5 \%$

$C G$, stone bars and RR, in order to protect the forest road ditches. The results showed that the lowest sediment yield was related to RR, GC and GC on CG. The main cause for this result is due to the difference in the aggregate size of RR used in two studies. The presence of fine and unwashed particles in stream materials used for the present study has led to more sediment yield, so that, among the conservation treatments, the use of RR led to a significant increase in the sediment yield rate at a flow intensity of $101 \mathrm{~s}^{-1}$. In the study by Lang (2016), the materials used had no fine particles. The smooth surface and the presence of cracks in RR increased runoff velocity and canalization in the cracks, which increased sediment concentration at flow intensity of $101 \mathrm{~s}^{-1}$. Sediment concentration of GC at $101 \mathrm{~s}^{-1}$ flow intensity was higher than CG and WW due to soil disturbance of plantation. The plantation operations also increased the cost of grass establishment (Shixiong Cao et al. 2006, Zhou and Shangguan 2007).

In the $\mathrm{Ctl}$ and RR, sediment concentration at flow intensity of $101 \mathrm{~s}^{-1}$ was significantly higher than at the flow intensity of $51 \mathrm{~s}^{-1}$ (Table 2). The reason for this is the higher runoff velocity in the $\mathrm{Ctl}$ and $\mathrm{RR}$ compared to other treatments. This is consistent with the study results of Lyle and Smerdon (1965) and Cao et al. (2009). They reported that an increase in shear stress of runoff due to increased flow velocity was the main factor in increasing sediment concentration. At both flow rate of $51 \mathrm{~s}^{-1}$ and $101 \mathrm{~s}^{-1}$, the sediment concentration generally increased quickly during the $0-5 \mathrm{~min}$ period, especially on Ctl. It then decreased slowly and in some cases remained steady until the end of the runoff simulation because of soil saturation with water (Fig. 5). 

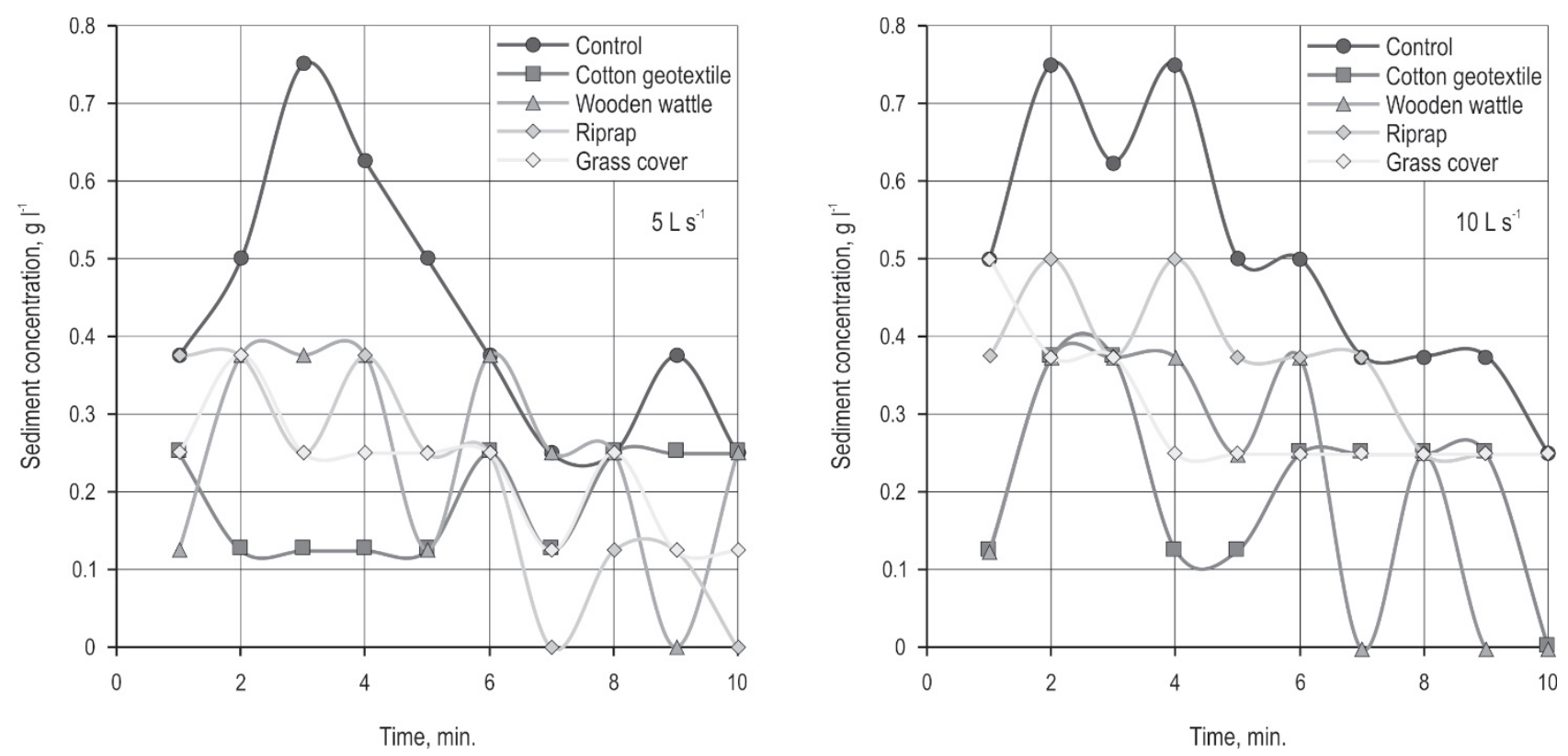

Fig. 5 Behavior of sediment concentration at flow rate of 5 and $10 \mathrm{I} \mathrm{s}^{-1}$ as function of time

\subsection{Effect of Conservation and Flow Treatments on Runoff Velocity}

In this study, the lowest runoff velocity was obtained for GC and WW and the highest for RR and CG (Table 3). Grass biomass with long and narrow leaves and stems can increase surface tortuosity and, therefore, decreases the runoff velocity. WW acts as check dam to reduce the velocity of concentrated water flow, and reduces erosion and sediment. Check dams are found to modify water and sediment transport by impounding runoff flow, reducing its velocity and peak rate, decreasing channel slope and allowing more time for infiltration and sediment deposition (Yuan et al. 2019), but as noted above, infiltration and consequently water penetration into the sub base of the forest road is not acceptable in road conservation practices. Except for the Ctl and CG, the flow rate conversion from $51 \mathrm{~s}^{-1}$ to $101 \mathrm{~s}^{-1}$ did not significantly change the runoff velocity. In the $\mathrm{Ctl}$ and $\mathrm{CG}$, the runoff velocity at a flow intensity of $10 \mathrm{l} \mathrm{s}^{-1}$ was significantly higher than at the flow intensity of $5 \mathrm{~s}^{-1}$ (Table 3). High bulk density in CG and consequently, lower porosity, contributed to accelerate the runoff velocity. In these conditions, the runoff initiated quickly in the ditch segment. Other authors have observed low sediment transport in plots with relatively high bulk density (Rodrigo Comino et al. 2016).

\section{Conclusion}

Hydrological behavior and sedimentation responses of the road ditches may be strongly influenced by the type of conservation treatments. Ditches collect surface runoff from the surrounding areas and roads.

Table 3 Comparison of different treatments in terms of runoff velocity (Ctl: control, CG: cotton geotextile, WW: wooden wattle, RR: riprap, GC: grass cover)

\begin{tabular}{|c|c|c|c|c|c|c|c|c|}
\hline \multirow{2}{*}{ Variables } & \multirow{2}{*}{ Flow rates } & & \multicolumn{5}{|c|}{ Treatment } & \multirow[t]{2}{*}{ ANOVA, $p$} \\
\hline & & & Control & Cotton geotextile & Wooden wattle & Riprap & Grass cover & \\
\hline \multirow{4}{*}{ Runoff velocity, $\mathrm{m} \mathrm{s}^{-1}$} & \multirow{2}{*}{$5 \mid s^{-1}$} & Mean & $0.62^{\mathrm{a}}$ & $0.12^{c}$ & $0.10^{c}$ & $0.25^{b}$ & $0.13^{\mathrm{c}}$ & \multirow{2}{*}{0.002} \\
\hline & & Standard deviation & 0.07 & 0.01 & 0.01 & 0.03 & 0.01 & \\
\hline & \multirow{2}{*}{$10 \mid s^{-1}$} & Mean & $0.96^{\mathrm{a}}$ & $0.32^{b}$ & $0.18^{c}$ & $0.38^{b}$ & $0.17^{c}$ & \multirow{2}{*}{0.004} \\
\hline & & Standard deviation & 0.08 & 0.03 & 0.01 & 0.04 & 0.01 & \\
\hline
\end{tabular}

Different superscripts in a row show significant difference at probability level of $5 \%$ 
The amount of runoff collected by ditches depends on the type of treatments for soil erosion control. Some treatments, such as grass cover, decrease the ditch storage capacity. In addition, uncompacted bed, soil disturbance and unwashed materials are major threats to ditch, especially with grass cover and riprap treatments. Compacted bed and dense cover of geotextile in ditch maintain soil particles in place and consequently decrease the sediment yield. In case of wooden wattle, the amount of sediment yield from the treated segment was low like that of cotton geotextile, but in this treatment the runoff velocity decreased to $0.18 \mathrm{~m} \mathrm{~s}^{-1}$ and this means that water has enough time to penetrate the uncompacted soil and road base, and this issue is not acceptable. The treatments that cause water infiltration are only recommended when the shape of the slopes and ditches prevent water from penetrating the sub base of the road. Adequate conservation treatments and road construction policies should be considered for the selection of ditch erosion control materials, especially in sensible road ditches. Different geotextiles filled by cotton and/or straw can be useful materials to be used in filtering and capturing the suspended sediments in runoff.

\section{References}

Afzalimehr, H., Dey, S., 2009: Influence of bank vegetation and gravel bed on velocity and Reynolds stress distributions. International Journal of Sediment Research 24(2): 236-246. https://doi.org/10.1016/S1001-6279(09)60030-5

Appelboom, T.W., Chescheir, G.M., Skaggs, R.W., Hesterberg, D.L., 2002: Management practices for sediment reduction from forest roads in the coastal plains. Transactions of the ASAE (American Society of Association Executives) 45(2): 337-344. https://doi.org/10.13031/2013.8529

Broda, J., Gawlowski, A., Rom, M., Laszczak, R., Mitka, A., Przybylo, S., 2016: Innovative Geotextiles for Reinforcement of Roadside Ditch. Tekstilec 59(2): 115-120. https://doi. org/10.14502/Tekstilec2016.59.115-120

Boulange, J., Malhat, F., Jaikaew, P., Nanko, K., Watanabe, H., 2019: Portable rainfall simulator for plot-scale investigation of rainfall-runoff, and transport of sediment and pollutants. International Journal of Sediment Research 34(1):38-47. https://doi.org/10.1016/j.ijsrc.2018.08.003

Burroughs, E.R., Foltz, R.B., Robichaud, P.R., 1991: Sediment production from forest roads and timber harvest areas. Our California Environment 1(4): 4-6.

Cao, L., Zhang, K., Zhang, W., 2009: Detachment of road surface soil by flowing water. Catena 76(2): 155-162. https://doi. org/10.1016/j.catena.2008.10.005

Cerdá, A., 2001: Effects of rock fragment cover on soil infiltration, interrill runoff and erosion. European Journal of Soil Science 52(1): 59-68. https://doi.org/10.1046/j.1365-2389. 2001.00354.x
Coker, R.J., Fahey, B.D., Payne, J.J., 1993: Fine sediment production from truck traffic, Queen Charlotte Forest, Marlborough Sounds, New Zealand. Journal of Hydrology 31(1): 56-64.

Daly, K., Tuohy, P., Peyton, D., Wall, D.P., Fenton, O., 2017: Field soil and ditch sediment phosphorus dynamics from two artificially drained fields on poorly drained soils. Agricultural Water Management 192: 115-125. https://doi. org/10.1016/j.agwat.2017.07.005

Demir, M., Hasdemir, M., 2005: Functional planning criterion of forest road network system according to recent forestry development. Turkish Journal of Engineering and Environmental Sciences 1(2): 8-22. https://doi.org/10.3844/ ajessp.2005.22.28

Dollinger, J., Vinatier, F., Voltz, M., Dagès, C., Bailly, J.S., 2017: Impact of maintenance operations on the seasonal evolution of ditch properties and functions. Agricultural Water Management 193: 191-204. https://doi.org/10.1016/j.agwat.2017.08.013

Efta, J.A., Chung, W., 2014: Planning Best Management Practices to Reduce Sediment Delivery from Forest Roads Using WEPP: Road Erosion Modeling and Simulated Annealing Optimization. Croatian Journal of Forest Engineering 35(2): 167-178.

Falbo, K., Schneider, R.L., Buckley, D.H., Walter, M.T., Buchanan, B.P., 2013: Roadside ditches as conduits of fecal indicator organisms and sediment: Implications for water quality management. Journal of Environmental Management 128: 1050-1059. https://doi.org/10.1016/j.jenvman.2013.05.021

Flora, C., Kröger, R., 2014: Use of vegetated drainage ditches and low-grade weirs for aquaculture effluent mitigation: I. Nutrients. Aquacultural Engineering 60: 56-62. https://doi. org/10.1016/j.aquaeng.2014.04.007

Foltz, R.B., Copeland, N.S., Elliot, W.J., 2009: Reopening abandoned forest roads in Northern Idaho, USA: Quantification of runoff, sediment concentration, infiltration, and interrill erosion parameters. Journal of Environmental Management 90: 2542-2550. https://doi.org/10.1016/j.jenvman.2009.01.014

Forsyth, A.R., Bubb, K.A., Cox, M.E., 2006: Runoff, sediment loss and water quality from forest roads in a southeast Queensland coastal plain Pinus plantation. Forest and Ecology Management 221(1-3): 194-206. https://doi.org/10.1016/j. foreco.2005.09.018

Galia, T., Šilhán, K., Škarpich, V., 2017: The geomorphic impacts of culverts at paved forest roads: Examples from Carpathian headwater channels, Czech Republic. Catena 157: 424-435. https://doi.org/10.1016/j.catena.2017.06.007

Hamed, Y., Albergel, J., Pepin, Y., Asseline, J., Nasri, S., Zante, P., Betndtsson, R., El-Niazy, M., Balah, M., 2002: Comparison between rainfall simulator erosion and observed reservoir sedimentation in an erosion-sensitive semiarid catchment. Catena 50(1): 1-16. https://doi.org/10.1016/S0341-8162(02) 00089-9

Haahti, K., Younis, B.A., Stenberg, L., 2014: Unsteady flow simulation and erosion assessment in a ditch network of a drained peatland forest catchment in eastern Finland. Water 
Resources Management 28(14): 5175-5197. https://doi. org/10.1007/s11269-014-0805-x

Javadi, P., Roohipour, H., Mahboubi, A., 2005: Effect of rock fragments cover on erosion and overland flow using flume and rainfall simulator. Iranian Journal of Rangeland and Desert Research 12(3): 288-310.

Jia, Z., Chen, C., Luo, W., Zou, J., Tang, Y., 2019: Hydraulic conditions affect pollutant removal efficiency in distributed ditches and ponds in agricultural landscapes. Science and Total Environment 649: 712-721. https://doi.org/10.1016/j. scitotenv.2018.08.340

Kumwimba, M.N., Zhu, B., Wang, T., Muyembe, D.K., 2016: Distribution and risk assessment of metals and arsenic contamination in man-made ditch sediments with different land use types. Environmental Science and Pollution Research 23(24): 24808-24823. https://doi.org/10.1007/s11356-0167690-1

Lang, A.J., 2016: Soil Erosion from forest haul roads at stream crossings as influenced by road attributes. P.hD thesis in Forest Resources and Environmental Conservation, Virginia Polytechnic Institute and State University, USA, 158 p.

Lin, Z., Niu, F., Liu, H., Lu, J., 2011: Disturbance-related thawing of a ditch and its influence on roadbeds on permafrost. Cold Regions Science and Technology 66(2-3): 105-114. https://doi.org/10.1016/j.coldregions.2011.01.006

Luce, C.H., Black, T.A., 1999: Sediment production from forest roads in western Oregon. Water Resources Research 35(8): 2561-2570. https://doi.org/10.1029/1999WR900135

Lotfalian, M., Yousefi Babadi, T., Akbari, H., 2019: Impacts of soil stabilization treatments on reducing soil loss and runoff in cutslope of forest roads in Hyrcanian forests. Catena 172: 158-162. https://doi.org/10.1016/j.catena.2018.08.023

Lyle, W.M., Smerdon, E.T., 1965: Relation of compaction and other soil properties to erosion resistance of soils. Transactions of the ASAE (American Society of Association Executives) 8(3): 419-422. https://doi.org/10.13031/2013.40536

Matthew, T., Streeter, K., Schilling, E., 2020: Assessing and mitigating the effects of agricultural soil erosion on roadside ditches. Journal of Soils and Sediments 20(1): 524-534. https:// doi.org/10.1007/s11368-019-02379-3

Nearing, M.A., Bradford, J.M., Parker, S.C., 1991: Soil detachment by shallow flow at low slopes. Soil Science Society of America Journal 55(2): 339-344. https://doi.org/10.2136/ sssaj1991.03615995005500020006x

Robichaud, P.R., Brown, R.E., 2002: Silt fences: an economic technique for measuring hillslope soil erosion. USDA Forest Service General Technical Report RMRS-GTR-95, Rocky Mountain Research Station, Fort Collins, CO, 24 p.

Rodrigo-Comino, J.R., Quiquerez, A., Follain, S., Raclot, D., Le Bissonnais, Y., Casalí, J., Pereira, P., 2016: Soil erosion in sloping vineyards assessed by using botanical indicators and sediment collectors in the Ruwer-Mosel valley. Agriculture, Ecosystems \& Environment 233: 158-170. https://doi. org/10.1016/j.agee.2016.09.009

Sheridan, G., Noske, P., Lane, P., Sherwin, C., 2008: Using rainfall simulation and site measurements to predict annual inter rill erodibility and phosphorus generation rates from unsealed forest roads: Validation against in-situ erosion measurements. Catena 73(1): 49-62. https://doi.org/10.1016/j.catena.2007.08.006

Shixiong Cao, C., Chen, L., Gao, W., Chen, Y., Yan, M., 2006: Impact of planting grass on terrene roads to avoid soil erosion. Landscape and Urban Planning 78(3): 205-216. https:// doi.org/10.1016/j.landurbplan.2005.07.007

Streeter, M.T., Schilling, K.E., Clair, M.St., 2019: Soil sedimentation and quality within the roadside ditches of an agricultural watershed. Science and Total Environment 657: 14321440. https://doi.org/10.1016/j.scitotenv.2018.12.113

Schilling, K.E., Streeter, M.T., Clair, M.St., Meissen, J., 2018: Subsurface nutrient processing capacity in agricultural roadside ditches. Science and Total Environment 637-638: 470479. https://doi.org/10.1016/j.scitotenv.2018.05.028

Stenberg, L., Tuukkanen, T., Finér, L., Marttila, H., Koivusalo, H., 2015: Ditch erosion processes and sediment transport in a drained peatland forest. Ecological Engineering 75: 421433. https://doi.org/10.1016/j.ecoleng.2014.11.046

Tague, C., Band, L., 2001: Simulating the impact of road construction a forest harvesting on hydrological response. Earth Surface Process and Landforms 26(2): 131-151. https://doi. org/10.1002/1096-9837(200102)26:2<135::AIDESP167>3.0.CO;2-J

Yuan, S., Li, Z., Li, P., Xu, G., Gao, H., Xiao, L., Wang, F., Wang, T., 2019: Influence of check dams on flood and erosion dynamic processes of a small watershed in the Loss Plateau. Water 11(4): 834-850. https://doi.org/10.3390/w11040834

Wang, X., Li, Z., Cai, C., Shi, Z., Xu, Q., Fu, Z., Guo, Z., 2012: Effects of rock fragment cover on hydrological response and soil loss from Regosols in a semi-humid environment in South-West China. Geomorphology 151-152: 234-242. https://doi.org/10.1016/j.geomorph.2012.02.008

Williams, J., Ross, P.J., Bristow, K.L., 1992: Prediction of the Campbell water retention function from texture, structure and organic matter. In: (Eds M.Th. van Genuchten, F.J. Leij, L.J. Lund). Proceedings of an International Workshop on Indirect Methods for Estimating the Hydraulic Properties of Unsaturated Soils. University of California, Riverside, CA, 427-442 p.

Zhou, Z.C., Shangguan, Z.P., 2007: The effects of ryegrass roots and shoots on loess erosion under simulated rainfall. Catena 70(3): 350-355. https://doi.org/10.1016/j.catena.2006.11.002 
Authors' addresses:

Rasoul Khandouzi, MSc

e-mail: rasool.khan8286@gmail.com

Assist. prof. Aidin Parsakhoo, PhD *

e-mail: parsakhoo@gau.ac.ir

Gorgan University of Agricultural Sciences

and Natural Resources

Faculty of Forest Science

Department of Forestry

Gorgan

IRAN

Assoc. prof. Vahedberdi Sheikh, $\mathrm{PhD}$ e-mail: Sheikh@gau.ac.ir

Aliakbar Mohamadali Pourmalekshah, MSc e-mail: pourmalekshah@gmail.com

Gorgan University of Agricultural Sciences and Natural Resources

Faculty of Rangeland and Watershed

Department of Watershed Management

Gorgan

Received: May 28, 2019

IRAN

Accepted: September 10, 2019

* Corresponding author 